\section{ENTITAS BISNIS DAN \\ PENGEMBANGAN PARIWISATA \\ KABUPATEN SUMENEP}

Enza Resdiana, M.AB

Dra. Irma Irawati P, M.Si

enza.resdiana@gmail.com

irma.puspaningrum@gmail.com

ABTRACT

Entitas bisnis dalam pengembangan pariwisata memiliki peran yang signifikan, secara garis besarnya adalah menyediakan jasa, memperluas berbagai fasilitas dan promosi. Pengembangan pariwisata juga membutuhkan peran serta pemerintah daerah dalam menjalin hubungan kerja sama yang baik sehingga dengan untuk lebih kreatif, inovatif dan mandiri dalam mengembangkan potensi pariwisata di masing-masing daerah. Dalam pengembangan pariwisata, pola kemitraan maupun pemerintahan kolaboratif diperlukaan untuk mendukung tercapainya visi pemerintah serta efektifitas pengelolaan pariwisata.

Tujuan dari penelitian ini yaitu untuk Mengetahui Entitas Bisnis Dan Pengembangan Pariwisata Kabupaten Sumenep. Aktor-aktor yang terlibat dalam penelitian ini adalah Disbudparpora, Pemilik Usaha Hotel, Biro Perjalanan, Pengelolaan tempat wisata dan Pelanggan.

Metode penelitian yang digunakan adalah Deskriptif Kualitatif. Data yang digunakan terdiri dari data primer dan data sekunder. Teknik pengumpulan data yang digunakan melalui observasi, wawancara dan dokumentasi.

Hasil penelitian ini menunjukkan bahwa Entitas Bisnis memiliki peran dalam mendukung pengembangan pariwisata Kabupaten Sumenep masih belum optimal, meskipun pada dasarnya Entitas Bisnis telah mendorong peningkatan investasi dengan memperhatikan kearifan lokal, kerjasama pendampingan dan pembinaan dalam mengembangkan ekonomi masyarakat, namun wisatawan masih kesulitan mencari galery souvenir atau pusat oleh-oleh. Disamping itu pula masih kurang maksimal melibatkan hotel-hotel dalam promosi wisata maupun kegiatan eveneven wisata.

KATA KUNCI: Entitas Bisnis, Pengembangan Pariwisata

\section{PENDAHULUAN}

Kabupaten Sumenep yang berada diujung timur, merupakan salah satu dari 4 (empat) kabupaten yang ada di Pulau Madura provinsi Jawa Timur yang terletak diantara 1130 32' 54" - 11601160 16' 48'" Bujur Timur dan 40 55' - 70 24' Lintang Selatan dengan luas wilayah 2.093.458 km2. (data BPS Jawa Timur 2016). Sebagai Kabupaten yang berada di ujung timur pulau Madura, Sumenep memiliki banyak potensi yang berkaitan dengan Pariwisata. Kabupaten Sumenep adalah wilayah yang unik karena merupakan selain terdiri dari wilayah daratan juga memiliki wilayah kepulauan yang tersebar berjumlah 126 pulau. Oleh sebab itu, Kabupaten Sumenep memiliki berbagai macam wisata yang begitu indah.

$$
\text { Kekayaan potensi wisata }
$$

Kabupaten Sumenep merupakan salah satu daerah wisata terlengkap di Jawa Timur, dan potensi dimana potensi wisata alam dan budaya yang dimiliki tidak dimiliki oleh daerah lain. Jika ingin mengembangkan sektor pariwisata harus 
melihat kondisi daerah setempat, sehingga peran serta masyarakat, sehingga keinginan pemerintah Kabupaten Sumenep untuk mengembangkan potensi wisata bisa terwujud.

menurut Paturusi (2007:47), mengungkapkan bahwa pengembangan adalah suatu strategi yang dipergunakan untuk memajukan, memperbaiki dan meningkatkan kondisi kepariwisataan suatu objek dan dayatarik wisata sehingga dapat dikunjungi wisatawan serta mampu memberikan manfaat bagi masyarakat disekitar objek dan dayatarik wisata maupun bagi pemerintah. Kabupaten Sumenep terus melakukan perbaikan dan pengembangan di segala bidang, salah satunya di bidang pariwisata. Pariwisata sudah menjadi primadona baru bagi perekonomian bangsa karena pertumbuhannya yang begitu menjanjikan terhadap kesejahteraan masyarakat.

Potensi wisata saat ini harus menjadi bagian industri secara global, agar bisa mensejahterakan masyarakat. Ini sesuai dengan salah satu misi Kabupaten Sumenep "Pemanfaatan dan pemberdayaan potensi sumber daya alam, termasuk sektor pariwisata yang berwawasan lingkungan". Sebagaimana pula tercantum dalam Peraturan Daerah Kabupaten Sumenep Nomor 4 Tahun 2018 tentang Rencana Induk
Pembangunan Kepariwisataan Kabupaten Sumenep tahun 2018-2025.

Setiap daerah memiliki berbagai potensi wisata yang dapat dikembangkan dan dikelola untuk dapat berdaya saing dengan wisata-wisata lain serta mendorong daya minat wisatawan baik nusantara maupun asing untuk melakukan kunjungan. Berbagai potensi wisata yang dimiliki daerah biasanya berupa wisata pantai, wisata pegunungan, wisata budaya, wisata kuliner, wisata religi, wisata kesehatan dan wisata-wisata lain yang dapat dibuat oleh pemerintah bersamasama stake holder.

Dalam mengembangkan potensi pariwisata daerah, diperlukan adanya sinergi antara berbagai pihak yang saling terkait agar wisata dapat dikembangkan dengan optimal dan mencapai target yang direncanakan. Dalam konsep good governance, pola kemitraan yang sinergis sangat dibutuhkan baik dilingkungan birokrasi maupun diluar pemerintahan. Pemerintah perlu melakukan mitra dengan privat sector (sektor swasta) dan civil society (masyarakat sipil). Pada pola seperti ini, penyelenggaraan jasa layanan atau fungsi pemerintah tertentu tidak lagi didominasi oleh satu pihak. Sebagaimana dinyatakan oleh Hayat (76;2017) bahwa setiap lembaga atau instansi negara untuk mencapai tujuan, tentunya harus 
melibatkan seluruh stakeholder yang ada dengan berbagai instrumen yang digunakan dan sumber dana yang memadai baik sumber daya manusia, sumber daya infrastruktur, maupun sumber daya dana atau sumber daya lainnya yang mendukung dalam pencapaian tujuan tersebut.

Pemerintah perlu mengajak dan mendorong peran aktif dari sektor swasta dan masyarakat sipil untuk bersama-sama menyatukan visi dalam pengembangan potensi wisata (Zaenuri, et al,2015). Pemetintah memiliki keterbatasan kapasistas dan penyediaan ruang yang perlu berkolaborasi dengan pihak swasta serta keterbatasan sumber daya dan pengamanan yang perlu dikuatkan oleh masyarakat sipil.

Peran pemerintah dalam pengembangan pariwisata secara garis besarnya adalah menyediakan infrastruktur, memperluas berbagai fasilitas, kegiatan kordinasi antara aparatur pemerintah dengan pihak swasta, pengaturan dan promosi. Dalam hal ini pemerintah mempunyai otoritas pengaturan, penyediaan dan peruntukan berbagai infrastruktur yang terkait dengan kebutuhan pariwisata. Infrastruktur merupakan aspek penting dalam pengembangan destinasi wisata. tanpa infrastruktur yang baik tidak mungkin dapat memajukan sektor wisata. Maka komitmen pemerintah sangat penting dalam meningkatkan infrastruktur dan melengkapi sarana dan prasarana yang diperlukan untuk meningkatkan daya tarik wisatawan.

Adapun peranan swasta dan masyarakat sebagaimana termuat dalam UU No. 10 Tahun 2009 tentang Kepariwisataan menyatakan bahwa, masyarakat memiliki kesempatan yang sama dan seluas luasnya untuk berperan serta dalam penyelenggaraan kepariwisataan. Ada aspek yang tidak bisa diperankan sepenuhnya oleh pemerintah, sehingga memutuhkan peran aktif dari swasta dan masyarakat seperti kemanan dan transportasi. Keamanan menjadi salah satu aspek penting untuk mengikat daya tarik wisatawan, ketika kondisi daerah dan lingkungan wisata tidak memiliki jaminan keamanan maka pengembangan wisata akan sulit mencapai kemajuan.

Kemudian untuk mendukung keberadaan dan kelengkapan transportasi dilingkungan pariwisata serta menghubungkan dengan area-area translit dan antar wisata. kelengkapan transportasi tidak kalah penting dengan keamanan, pemerintah dapat bekerjasama dengan pihak-pihak swasta untuk melengkapi sarana transportasi. Dalam hal ini entitas bisnis atau swasta tetapi masyarakat dan swasta memiliki andil besar untuk memerankan promosi pariwisata. 
Kabupaten Sumenep memiliki banyak potensi yang cukup strategis untuk dikembangkan dalam menunjang pembangunan daerah dan pendapatan daerah. beberapa potensi wisata yang dimiliki sumenep diantaranya adalah wisata alam yang terdiri dari Pantai Lombang, Pantai Salopeng, Pantai Sembilan, Pantai Gili Labak. Kemudian wisata budaya dan religi, wisata kesehatan berupa kadar oxsigen terbaik ke-dua di dunia, wisata kuliner dan wisata buatan. Kekayaan potensi destinasi wisata menjadi tantangan tersendiri bagi pemerintah dan stakeholder untuk bersama-sama mengelola dan mengembangkan agar lebih bermanfaat dan berdampak pada kemajuan daerah.

Dalam hal pengembangan ini diperlukan dukungan dari pihak swasta atau entitas bisnis yang dapat mengembangkan fasilitas yang memadai dalam rangka mendukung pengembangan wisata yang dilakukan oleh pemerintah daerah. Entitas bisnis memiliki peran dalam rangka memberikan fasilitas dan jasa yang memilki kualitas untuk memenuhi kebutuhan dari pelanggan atau yang disebut dengan pengunjung wisata. Peran aktif dari entitas bisnis diperlukan untuk membantu pemerintah Daerah dalam melakukan pembangunan dan pengembangan wisata sehingga dengan peran dari entitas bisnis ini dapat memberikan nilai yang positif bagi perkembangan wisata di suatu daerah.

Begitupun juga pengembangan wisata di Kabupaten Sumenep membutuhkan dukungan dan sinergitas antara Pemerintah Daerah dengan entitas bisnis sehingga dengan memilki sinergi yang baik maka pengembangan wisata yang dilakukan oleh Kabupaten Sumenep akan didukung dengan fasilitas yang ditawarkan oleh beberapa entitas bisnis. Dalam hal ini entitas bisnis berperan untuk memberikan fasiltas dan jasa yang akan dibutuhkan oleh pengunjung wisata seperti kebutuhan akan Biro perjalanan yang menyediakan paket-paket kunjungan wisata di Kabupaten Sumenep, Rumah makan yang menyediakan makanan khas Sumenep, Penginapan atau hotel yang memiliki kualitas yang memadai yang juga ikut membantu mepromosikan wisata di Kabupaten Sumenep.

Dibutuhkan kerja sama antara entitas bisnis dengan Pemerintah Daerah sehingga dengan terciptanya kerja sama ini maka entitas bisnis memiliki kompetensi yang memadai untuk memberikan pelayanan dan fasilitas yang terbaik untuk pengunjung wisata.

Berkaitan dengan hal tersebut Bahwa pariwisata di sebuah daerah akan berkembang lebih baik dan cepat jika 
didukung oleh entitas bisnis dan pemerintah yang saling bersinergi karena tanpa dukungan pembangunan (pengembangan) kepariwisataan yang digagas oleh pemerintah daerah akan banyak menemui kendala maupun tantangan tanpa didukung oleh entitas bisnis yang ada di Kabupaten Sumenep. Dengan demikian penulis menetapkan penelitian yaitu "Entitas Bisnis Dan Pengembangan Pariwisata Kabupaten Sumenep"?

\section{LANDASAN TEORI}

\section{A. Pengembangan}

\section{Menurut Moekijat dalam Paramasari (2009) pengertian pengembangan adalah setiap usaha untuk memperbaiki pelaksanaan pekerjaan yang sekarang maupun yang akan datang, dengan memberi keterangan, mempengaruhi sikap- sikapataumenambahkecakapan.

Sedangkan menurut Malthis
dalam Kadarisman (2013:127)
mengemukakan pengembangan dapat
dilihat sebagai pertumbuhan kemampuan
yang terjadi jauh melampaui apa-apa yang
dituntut dalam suatu pekerjaan, hal ini
mewakili usaha-usaha dalam
meningkatkan kemampuan karyawan
untuk menangani berbagai jenis
penugasan.

\section{Menurut Dumasari (2014:1)} konsep pengembangan merupakan usaha atau upaya yang dilakukan bersama secara terencana dan sistematis untuk meningkatkan kualitas kehidupan manusia dalam berbagai bidang seperti ekonomi, budaya, politik, teknologi, ilmu pengetahuan, pendidikan, pertanian, pangan, kesehatan dan sebagainya. Pengembangan sebagai suatu proses yang bertujuan untuk mencapai kondisi kehidupan masyarakat yang lebih baik, layak, beradap, bermartabat, bermakna, makmur dan sejahtera.

Sedangkan menurut Paturusi (2007:47), mengungkapkan bahwa pengembangan adalah suatu strategi yang dipergunakan untuk memajukan, memperbaiki dan meningkatkan kondisi kepariwisataan suatu objek dan dayatarik wisata sehingga dapat dikunjungi wisatawan serta mampu memberikan manfaat bagi masyarakat disekitar objek dan dayatarik wisata maupun bagi pemerintah.

\section{B. Pariwisata}

Menurut Prof. Salah Wahab, pariwisata adalah suatu aktivitas manusia yang dilakukan secara sadar dan mendapat pelayanan secara bergantian di antara orang-orang dalam suatu Negara itu sendiri ataupun di luar negeri, meliputi pendiaman orang-orang dari daerah lain untuk sementara waktu dalam mencari dan memperoleh kepuasan yang beraneka ragam dan berbeda dengan apa yang dialaminya (dimana ia tinggal).

Menurut Damanik dan Weber Pariwisata adalah merupakan fenomena pergerakan manusia, barang, dan jasa, yang sangat kompleks. Dan terkait erat dengan organisasi, hubungan-hubungan kelembagaan dan individu, kebutuhan layanan, penyediaan kebutuhan layanan, dan sebagainya.

\section{1) Pengembangan Pariwisata}

Menurut Oka A. Yoeti (2008:21) pengembangan suatu kawasan pariwisata meliputi:

a) Sebagian besar sumber daya fisik atau komponen produk wisata.

b) Analisis pengunjung potensial, kebijakan harga, dan destinasisaingan.

c) Aspek lingkungan, budaya, dan sosial. 
Berbeda dengan Gamal Suwantoro (2009:56) yang berpendapat bahwa pengembangan pariwisata sering dikaitkan dengan adanya Sapta Kebijakan Pengembangan Pariwisata oleh pemerintah, yaitu sebagai berikut:

a) Promosi pariwisata harus dilaksanakan secara selaras dan terpadu, baik di dalam negeri maupun luar negeri.

b) Aksesibilitas Merupakan salah satu aspek penting karena menyangkut pengembangan lintas sektoral.

c) Kawasan Pariwisata Pengembangan kawasan pariwisata dimaksudkan untuk:

1. Meningkatkan peran serta daerah dan swasta dalam pengembangan pariwisata.

2. Memperbesar dampak positif pembangunan.

3. Mempermudah pengendalian terhadap dampak lingkungan.

d) Wisata Bahari Wisata bahari merupakan salah satu jenis produk wisata yang sangat potensial untuk dikembangkan.

e) Produk Wisata Upaya untuk dapat menampilkan produk wisata yang bervariasi dan mempunyai kualitas daya saing yang tinggi.

f) Sumber Daya Manusia Sumber daya manusia merupakan salah satu modal dasar pengembangan pariwisata.

g) Kampanye Nasional Sadar Wisata Kampanye nasional sadar wisata pada hakikatnya adalah upaya memasyarakatkan Sapta Pesona yang turut menegakkan disiplin nasional dan jati diri bangsa Indonesia melalui kegiatan kepariwisataan.

\section{2) Komponen Pengembangan Pariwisata}

Komponen

pengembangan pariwisata dan hubungan internal menurut Inskeep (1991) dalam Hadiwijoyo (2012) menyatakan bahwa komponen pengembangan pariwisata dapat diklasifikasikan sebagai berikut :

1) Atraksi dan aktifitas pariwisata Semua atraksi baik yang bersifat alami, maupun khusus serta berbagai aktivitas yang berkaitan dengan kawasan yang menarik wisatawan untuk mengunjunginya

2) Akomodasi

Hotel dan fasilitas lainnya yang sejenis, serta jasa layanannya dimana wisatawan menginap selama waktu kunjungannya

3) Fasilitas dan jasa layanan wisata lainnya

Fasilitas-fasilitas dan jasa pelayanan yang diperlukan untuk pengembangan pariwisata, antara lain operasional tour and travel, restoran dan cafe, bank dan money changer, kantor informasi pariwisata, fasilitas keamanan dan sebagainya.

4) Fasilitas dan jasa layanan transportasi

Fasiltas dan jasa layanan transportasi meliputi akses transportasi masuk ke kota dan area pengembangan, sistem transportasi internal, penghubung lokasi wisata dan area pengembangannya, tarnsportasi dalam area pengembangan.

5) Infrastruktur lainnya, seperti air, listrik dan telekomunikasi.

6) Elemen instusional

Elemen ini penting untuk mengatur dan mengembangkan pariwisata. Elemen institusional antara lain berupa program perenanaan, pendidikan dan pelatihan SDM, promosi dan pemasaran strategis, kebijakan investasi, program pengendalian pengaruh ekonomi, lingkungan dan sosio kultural. 


\section{METODE PENELITIAN}

Penelitian ini dilakukan dengan metode kualitatif deskriptif dengan menitik beratkan pada observasi lapangan. Peneliti melakukan wawancara mendalam dalam menggali data yang dibutuhkan kepada subjek penelitian.

Sementara, yang menjadi Subjek dan Objek peneliti adalah Disbudparpora, Pemilik Usaha Hotel, Biro Perjalanan, Pengelolaan tempat wisata dan Pelanggan. Teknik pengumpulan data yang peneli kumpulkan, terdiri dari data primer melalui hasil wawancara mendalam dan observasi langsung yang dilakukan peneliti. Selain pengumpulan data diperoleh dari hasil dokumentasi dan kepustakaan (data sekunder) (Ahmad, 2015:212).

Teknik analisa data, yang dilakukan peneliti yaitu pertama, reduksi data yang merupakan proses pemilihan, pemusatan, perhatian pada penyederhanaan data dari semua data yang diperoleh. Kedua, penyajian data dilakukan dengan proses pengorganisasian untuk memudahkan data dianalisis dan disimpulkan. Ketiga, penarikan kesimpulan, yaitu membuat pernyataan atau kesimpulan secara bulat tentang suatu permasalahan yang diteliti dalam bahasa yang deskriptif dan bersifat interpretatif. (Sugiyono, 2016)
Adapun aktor-aktor yang menjadi sasaran penelitian serta rekomendasi untuk dijadikan mitra (sekaligus sebagai subyek penelitian) bagi pengembangan pariwisata adalah sebagai berikut Pemilik hotel, Pemilik home stay, Pengusaha kerajinan, Pengusaha kuliner dan Biro travel

\section{HASIL PENELITIAN}

Kabupaten Sumenep, memiliki banyak obyek wisata yang diminati dengan adanya potensi-potensi sumber daya kepariwisataan dan peninggalan sejarah serta kekayaan budaya merupakan potensi yang kuat untuk pengembangan kepariwisataan di Kabupaten Sumenep. Dan untuk mencapai daya guna dan hasil guna, pengembangan pariwisata di Kabupaten Sumenep perlu mempertimbangkan kesesuaian antara rencana pengembangan obyek wisata dengan kemampuan daerah. Berikut beberapa hasil wawancara kaitannya dengan perkembangan pariwisata di Kabupaten Sumenep.

Potensi wisata yang ada di Kabupaten Sumenep memiliki berbagai macam potensi wisata yaitu Wisata Keraton Sumenep Wisata Religi, Wisata Pantai, Wisata Alam,Wisata Kerajinan, Wisata Kesenian dan Wisata Budaya. Beraneka ragam wisata yang ada ini diperlukan dukungan dari entitas bisnis untuk menjadikan wisata yang berada di Kabupaten Sumenep memiliki jasa wisata 
yang dapat menunjang pengembangan wisata yang dilakukan oleh pemerintah. Dalam hal ini pemerintah harus mampu bersinergi dengan entitas bisnis sehingga dengan sinergi tersebut mampu menciptakan kerja sama yang mendorong ke arah yang lebih baik. Berikut ini beberapa Gambar Wisata Religi, Wisata Keraton, wisata alam dan wisata kesenian di Kabupaten Sumenep

Berbagai macam wisata yang berada di Sumenep seperti Gambar diatas yaitu wisata Religi, Wisata Keraton, Wisata alam dan Wisata Kesenian, wisata kerajinan dan wisata budaya membutuhkan peran aktif dari entitas bisnis untuk memdukung fasilitas dan jasa dalam menunjang kepariwisataan di Kabupaten Sumenep.

\section{A. Peran Aktif Entitas Bisnis}

Manfaat yang didapatkan dari industri pariwisata akan dirasakan oleh para pemangku kepentingan yang terdiri atas pemerintah daerah, masyarakat dan dunia usaha, masing-masing pihak terkait memiliki peran dalam mengembangkan pariwisata daerah. Bahwa peran serta pelaku usaha sangat membantu dan mendorong sektor pariwisata di sebuah daerah, karena industri pariwisata melibatkan berbagai hal seperti transportasi, penginapan, restoran, pemandu wisata dan lain-lain.
Peran Aktif entitas bisnis terhadap pengembangan sektor wisata di Kabupaten Sumenep memiliki peran yang begitu besar dalam menyediakan berbagai pelayanan jasa untuk menunjang dan mendukung pengembangan wisata di Kabupaten Sumenep. berikut beberapa usaha jasa pariwisata yang berada di Kabupaten Sumenep.

DATA USAHA JASA PARIWISATA KABUPATEN SUMENEP

\begin{tabular}{|c|l|c|}
\hline NO & $\begin{array}{l}\text { NAMA } \\
\text { USAHA }\end{array}$ & JENIS USAHA \\
\hline \multirow{2}{*}{1} & $\begin{array}{l}\text { CITRA } \\
\text { ABABIL } \\
\text { GROUP }\end{array}$ & $\begin{array}{c}\text { ANGEN } \\
\text { WISATA }\end{array}$ \\
\hline 2 & $\begin{array}{l}\text { CV. } \\
\text { YUDEWI }\end{array}$ & EVENT \\
& ORGANIZER \\
\hline
\end{tabular}

Sumber: Dinas Pariwisata, Kebudayaan, Pemuda, dan Olahraga Kabupaten Sumenep

Para pelaku usaha di kabupaten sumenep juga tidak ketinggalan berperan aktif dalam menyiapkan fasilitas wisatawan yang nyaman sebagai bagian dari uapaya mendukung pengembangkan wisata. Pelaku usaha yang menjadi unit analisis dalam hal ini adalah penyedia hotel dan biro perjalanan.

Pertama. Biro perjalanan yang ada di Sumenep berjumlah 24 (dua puluh empat) sesuai data disbudparpora. Hal ini dapat dilihat dengan Tabel berikut ini

Data Usaha Pariwisata Bidang Usaha Biro Perjalanan Wisata Kabupaten Sumenep 


\begin{tabular}{|c|l|}
\hline NO & \multicolumn{1}{|c|}{ NAMA USAHA } \\
\hline 1 & $\begin{array}{l}\text { PT.ALMADDINAH } \\
\text { KLABAAN GULUK } \\
\text { GULUK }\end{array}$ \\
\hline 2 & $\begin{array}{l}\text { PT.ARRAUDHAH ABADI } \\
\text { INDAH }\end{array}$ \\
\hline 3 & $\begin{array}{l}\text { PT. MEDIA SYAIFUL } \\
\text { QULUB MADINAH }\end{array}$ \\
\hline 4 & $\begin{array}{l}\text { PT. FALISHA MULIA AL }- \\
\text { HADI }\end{array}$ \\
\hline 5 & $\begin{array}{l}\text { PT. NATA BERSAMA } \\
\text { TOUR \& TRAVEL }\end{array}$ \\
\hline 6 & $\begin{array}{l}\text { PT.LAN TABUR JAYA } \\
\text { WISATA }\end{array}$ \\
\hline 7 & CV. JELAJAH SUMENEP \\
\hline 8 & CV. AATIRA \\
\hline 9 & CV. KARTIKA DEWI \\
\hline 10 & CV. LAUT BIRU EXPRESS \\
\hline 11 & $\begin{array}{l}\text { CV. CITRA MANDIRI } \\
\text { WISATA }\end{array}$ \\
\hline 12 & PT. BRAMA RAHAYU \\
\hline 13 & $\begin{array}{l}\text { PT. AZFA NUR } \\
\text { HAROMAIN }\end{array}$ \\
\hline 14 & CV. SATU TIGA UTAMA \\
\hline 15 & CV. SURYA MANDIRI \\
\hline 16 & $\begin{array}{l}\text { PT. ANUGRAH NURANI } \\
\text { QANAAH }\end{array}$ \\
\hline 17 & $\begin{array}{l}\text { PT. CITRA RAYA TOUR \& } \\
\text { TRAVEL }\end{array}$ \\
\hline 18 & CV. PUTRI TUNGGAL \\
\hline 19 & $\begin{array}{l}\text { PT. BALQIS JAYA } \\
\text { SELAMANYA }\end{array}$ \\
\hline 20 & CV. BERSAUDARA \\
\hline 21 & $\begin{array}{l}\text { PT. ALFATIH CAHAYA } \\
\text { UTAMA }\end{array}$ \\
\hline CV. MADURA VACATION \\
\hline 24 & CVAFILAH ENERGY \\
\hline
\end{tabular}

Sumber: Dinas Pariwisata, Kebudayaan, Pemuda, dan Olahraga Kabupaten Sumenep
Keberadaan biro perjalan dianggap masih belum cukup jika dibandingkan dengan jumlah destinasi wisata yang sering dikunjungi yaitu sebenyak 25 (dua puluh lima) wisata. Kemudian berbanding dengan jumlah pengunjung, misalnya selama 5 bulan (januari, februari, maret, april, mei) yang rata-rata mencapai 91.401 wisman dan winus dalam sebulan. Maka jika dirasionalkan 1 biro perjalanan berbanding 1 wisata dan 3.808 wisatawan atau 150.000 wisatawan jika diambil $50 \%$ menggunakan jasa biro perjalanan. Tetapi jika mengacu pada jumlah wisatawan yang mengunakan biro perjalanan ternyata tidak cukup banyak, bahkan salah satu biro perjalanan pernah sekali mengantarkan wisatawan dalam kurun 3 bulan. Hanya biro-biro tertentu yang sering mengantarkan wisatawan dan sudah banyak kenalan atau network diluar daerah. Beberapa peran yang bisa dilakukan oleh Biro Travel dalam pengembangan pariwisata adalah :

a. Menjaga adat dan menghormati norma agama, adat istiadat, budaya dan nilai yang hidup dalam masyarakat.

b. Memberikan informasi pra perjalanan, literatur atau buku panduan lainnya tentang hal-hal yang terkait dengan destinasi wisata.

c. Sistem pengaturan jumlah kunjungan wisatawan untuk tidak melebihi daya 
tampung dari destinasi wisata yang dikunjungi.

d. Memiliki kemampuan berkomunikasi bahasa Asing (Inggris) dan meningkatkan tentang cara berkomunikasi serta menangani wisatawan ketika mereka berinteraksi langsung dengan lingkungan dan sosial budaya masyarakat destinasi wisata.

e. Menyediakan paket-paket wisata yang bisa membuat wisatawan tertarik untuk datang ke daerah mengunjungi destinasi wisata yang ditawarkan, sehingga terbentuk menjadi branding potensi wisata daerah.

f. Meningkatkan kompetensi tenaga biro melalui pendidikan dan pelatihan.

Kedua, penyedia penginapan atau hotel. Jumlah hotel yang ada di Sumenep kurang lebih berjumlah 14 hotel,

Data Penginapan dan Hotel Kabupaten Sumenep

\begin{tabular}{|c|l|}
\hline NO & \multicolumn{1}{|c|}{ NAMA } \\
\hline 1 & Hotel Utami Sumekar \\
\hline 2 & Hotel Sumekar \\
\hline 3 & Hotel Wijaya I \\
\hline 4 & Hotel Wijaya II \\
\hline 5 & Safari Jaya \\
\hline 6 & Hotel Mitra Land \\
\hline 7 & Losmen Baitul Kamul \\
\hline 8 & Wisma Sumekar \\
\hline 9 & Family Nur \\
\hline
\end{tabular}

\begin{tabular}{|l|l|}
10 & Hotel C1 \\
\hline 11 & Hotel Suramadu \\
\hline 12 & Garuda Hotel Sumenep \\
\hline 13 & Hotel Kangen \\
\hline 14 & Hotel Musdalifah \\
\hline
\end{tabular}

Sumber : www.pulaumadura.com > Hotel demikian sangat minim sekali jika dibandingkan dengan jumlah destinasi wisata dan jumlah pengunjung. Tetapi sebagaimana yang diungkap oleh salah satu pemilik hotel bahwa kebanyak yang menginap bukan dari wisatawan atau untuk kepentingan wisata tetapi kepentingan lain, kunjungan kantor dan bisnis. Artinya. Keberadaan hotel di Sumenep sudah cukup untuk menfasilitasi wisatawan, yang perlu di kembangkan adalah keberadaaan hotel atau homestay di kawasan-kawasan wisata. Karena kebanyakan sampai saat ini hotel-hotel ada dan ditemui lokasinya hanya di daerah kota saja. Beberapa peran yang dilakukan oleh pemilik usaha hotel adalah

a. Tentunya menjadikan pengunjung senyaman mungkin, memberikan pelayanan yang baik tanpa diskriminatif, menyiapkan informasi seputar wisata Sumenep dan event-event wisata.

b. Mengembangkan kemitraan dengan usaha mikro dan kecil serta koperasi setempat yang saling memerlukan, memperkuat dan menguntungkan. 
c. Mengutamakan penggunaan produk lokal masyarakat setempat sehingga menguatkan ekonomi masyarakat.

d. Memelihara lingkungan yang sehat, bersih dan asri.

e. Menjaga citra daerah melalui kegiatan usaha kepariwisataan secara bertanggung jawab.

f. Menerapkan standar usaha dan standar kompetensi sesuai dengan ketentuan peraturan yang berlaku.

g. Berpartisipasi mencegah segala bentuk perbuatan yang melanggar kesusilaan dan kegiatan yang melanggar hukum di lingkungan tempat usaha

Ketiga, pengusaha kuliner yang berada di Kabupaten Sumenep berjumlah 42 jasa kuliner. Jumlah kuliner yang ada ini merupakan salah satu bentuk nyata peran aktif dari entitas bisnis yang begitu besar sehingga dengan didukung oleh jumlah jasa rumah makan maka pengembangan wisata yang dilakukan oleh Pemerintah akan bersinergi dengan peran bisnis. Berikut adalah data-data industri usaha kuliner di Sumenep.

Data Industri Pariwisata Jenis Usaha Rumah Makan/Restaurant

\begin{tabular}{|c|l|}
\hline NO & \multicolumn{1}{|c|}{ NAMA USAHA } \\
\hline 1 & Resto Ayam Brewok Sakera \\
\hline 2 & Kedai HK \\
\hline 3 & Resto JBL \\
\hline 4 & Toby's Fried Chicken \\
\hline
\end{tabular}

\begin{tabular}{|c|l|}
\hline 5 & Warung Jawa Mojokerto \\
\hline 6 & Warung Up Normal \\
\hline 7 & Rumah Makan IBNU \\
\hline 8 & Warung Sejati \\
\hline 9 & RM. Ayoka \\
\hline 10 & Kedai Simple \\
\hline 11 & Anisa Jaya \\
\hline 12 & Kedai Pendekar \\
\hline 13 & Depot kaldu Kokot Sumekar \\
\hline 14 & Restoran Srikandi \\
\hline 15 & RM Wapo Pedas 333 \\
\hline 16 & Warung Keluarga \\
\hline 17 & Bakso Kondang 99 \\
\hline 18 & Warung Makan Berkat \\
\hline 19 & Rumah Makan Tiga Lima \\
\hline 20 & Ice Cream California \\
\hline 21 & RM. Avieta \\
\hline 22 & Depot Lesehan Ontel \\
\hline 23 & RM. Lesehan Marhaban \\
\hline 24 & Bakso Asli \\
\hline 25 & Warung Makan Bumi \\
\hline 26 & Whareank \\
\hline 27 & Warung Bu ITA \\
\hline 28 & Warung Lesehan Ayu \\
\hline 29 & RM. Mila Fasifik \\
\hline 30 & CV. Anita Family \\
\hline 31 & Kedai Gezo \\
\hline 32 & RM. Amanish \\
\hline 33 & Bakso Pak Mo \\
\hline 34 & RM. Man Nyaman \\
\hline 35 & RM. California Ice Cream \& \\
\hline 36 & Depot Raja A-4 \\
\hline 37 & Kedai Bu Wiwik blora \\
\hline 38 & Geslim Resto \\
\hline 39 & Warung KPK JOSS \\
\hline 40 & Kedai Princess \\
\hline 41 & Rumah Makan Rato \\
\hline 42 & Warung Jati \\
\hline & Dina Parwita, Kebudayan \\
\hline 12
\end{tabular}

Sumber: Dinas Pariwisata, Kebudayaan, Pemuda, dan Olahraga Kabupaten Sumenep

$$
\text { Peran aktif entitas Bisnis telah }
$$
mampu memberikan berbagai macam fasilitas dan jasa yang disediakan untuk 
mendukung pengembangan wisata di Kabupaten Sumenep, hal ini dapat dibuktikan dengan jumlah jasa biro perjalanan, jumlah kuliner, dan jumlah hotel yang ada di Kabupaten Sumenep telah mampu mendorong peningkatkan investasi dengan memperhatikan kearifan lokal, kerjasama pendampingan dan pembinaan dalam mengembangkan ekonomi masyarakat, namun wisatawan masih kesulitan mencari galery souvenir atau pusat oleh-oleh.

Salah satu kendala yang dihadapi oleh pengunjung wisata yaitu sulitnya mencari pusat oleh-oleh atau souvenir, entitas bisnis masih belum mampu merespon dengan baik berbagai kebutuhan ini. Meskipun secara jasa telah mampu memenuhi kebutuhan seperti jasa dalam bidang perjalanan, kuliner dan hotel akan tetapi kebutuhan akan pusat oleh-oleh yang disediakan untuk memuaskan pelanggan atau pengunjung wisata masih belum mampu merespon ini. Hal ini disebabkan karena koordinasi antara pemerintah dan entitas bisnis masih sangat minim sehingga berbagai kebutuhan yang dibutuhkan dalam fasilitas wisata di Kabupaten Sumenep masih belum bersinergi dengan baik.

Untuk biro perjalanan wisata sendiri entitas bisnis telah mampu merespon dengan baik kebutuhan dari pelanggan dengan disediakannya biro perjalanan paket-paket wisata yang ada di Kabupaten Sumenep seperti Paket wisata kunjungan wisata Religi, wisata alam, wisata keraton, dan wisata kesenian. Sedangkan untuk penyediaan jasa kuliner, entitas bisnis telah mampu mengembangkan rumah makan yang dapat dikunjungi oleh pelanggan atau pengunjung wisata dengan menyediakan menu makanan khas Madura dengan tersedianya jumlah Rumah maakan yang berjumlah 42 Rumah Makan maka pengunjung tidak akan kesulitan untuk menemukan makanan yang disukai karena penyediaan Rumah makan yang bervariasi.

Entitas bisnis juga telah mampu memberikan pelayanan dan fasilitas yang berkaitan dengan penyediaan penginapan dan hotel yang mempunyai kualitas. Penyediaan penginapan dan hotel di Kabupaten Sumenep pihak swasta atau entitas bisnis masih belum mampu bersinergi dengan pemerintah daerah karena setiap hotel yang berada di Kabupaten Sumenep masih belum mampu mendukung pemerintahn daerah untuk mempromosikan wisata yang ada di Kabupaten Sumenep.

\section{PENUTUP}

Pada kesimpulan ini peneliti menyimpulkan bahwa bahwa Entitas Bisnis dalam mendukung pengembangan 
pariwisata Kabupaten Sumenep memiliki peran aktif dalam pengembangan wisata akan tetapi masih belum optimal, meskipun pada dasarnya Entitas Bisnis telah mendorong peningkatan investasi dengan memperhatikan kearifan lokal, kerjasama pendampingan dan pembinaan dalam mengembangkan ekonomi masyarakat, namun wisatawan masih kesulitan mencari galery souvenir atau pusat oleh-oleh. Disamping itu pula masih kurang maksimal melibatkan hotel-hotel dalam promosi wisata maupun kegiatan even-even wisata. Kemitraan pengusaha dengan masyarakat, pihak pengusaha (hotel) masih kurang memanfaatkan potensi ekonomi masyarakat lokal sebagai bagian promosi ekowisata sehingga memberikan ruang kepada masyarakat untuk lebih meningkatkan usaha ekonomi mandiri dengan demikian bisa meningkatkan kesejateraan ekonomi masyarakat.

\section{Rekomendasi/Saran}

Entitas Bisnis dalam mendukung pengembangan Pariwisata di Kabupaten Sumenep mempunyai peran yang masih belum optimal sehingga dibutuhkan koordinasi dan kerja sama yang solid antara pihak swasta atau entitas bisnis dengan Pemerintah Daerah sehingga dengan kerja sama ini akan menjadikan pengembangan pariwisata di Sumenep akan berhasil.

\section{DAFTAR PUSTAKA}

Hadiwijoyo, Suryo Sakti, 2012, Perencanaan Pariwisata Perdesaan Berbasis Masyarakat. Graha Ilmu, Yogyakarta.

Jonathan Claresta Janice, Riswan Efendi Tarigan. 2016., "The Effects of etourism to the development of tourism sector in Indonesia"., Journal. CommIT (Communication \& Information Technology) Journal 10(2), 59-62, 2016.

Mariyono Joko., 2017., "Determinants of Demand for Foreign Tourism in Indonesia"., Journal, Avalaible online at http://journals.ums.ac.id Jurnal Ekonomi Pembangunan, 18 (1), 2017, 82-92.

Soekadijo. 1996. Anatomi Pariwisata: Memahami Pariwisata Sebagai Systemic Linkage. Jakarta: PT. Gramedia Pustaka Utama.

Yoeti, H Oka A., 2012, Perencanaan dan Pengembangan Pariwisata, PT. Pradnya Paramita, Jakarta.

Sugiyono, 2016, Metode Penelitian Administrasi, Bandung, Alfa Beta CV.

Undang-undang Nomor 10 Tahun 2009 tentang Kepariwisataan

Peraturan Bupati Sumenep Nomor 12 Tahun 2017 tentang Pedoman Pelaksanaan APBD Kabupaten Sumenep 